\title{
Aquilaria yunnanensis S.C. Huang (Thymelaeaceae), A New Record for the Flora of Vietnam
}

\author{
Hoang Van Sam ${ }^{1 *}$, Nguyen The Nha ${ }^{1}$, Tran Van Chu ${ }^{1}$, Nguyen Thanh Tuan ${ }^{1}$, Nguyen Thi Tho ${ }^{1}$, \\ Do Thanh Tam ${ }^{1}$, Le Bao Thanh ${ }^{1}$, Tran Ngoc Hai ${ }^{1}$, Ha Van Huan ${ }^{1}$, Hoang Thi Hang ${ }^{1}$, Duong Trung \\ Hieu ${ }^{2}$, Claudio Cerboncini ${ }^{3}$, Olarte Alexandra ${ }^{3}$ \\ ${ }^{1}$ Vietnam National University of Forestry, Hanoi, Vietnam \\ 2. North East College of Agriculture and Forestry, Quang Ninh, Vietnam \\ 3. Institute for Bio- and Geoscience, Jülich institute, Germany \\ * Corresponding author: samhv@vnuf.edu.vn
}

Abstract: Aquilaria yunnanensis S.C. Huang (Thymelaeaceae), known to be endemic to Yunnan, is recorded for the first time from Dong Son Ky Thuong Nature Reserve, Quang Ninh Province, Vietnam. A taxonomic description and DNA analysis based on our Vietnamese collections are presented, together with information on its distribution, habitat and colour photographs.

Keywords: Aquilaria, Dong Son Ky Thuong Natural Reserve, Thymelaeaceae, Vietnam.

\section{Introduction}

Aquilaria Lam. (Thymelaeaceae) is a well-known important tree genus providing agarwood. It is endemic to the Indo-Malesia region, largely occurring from southern China throughout the Malesian region extending to the Pacific Islands (Domke, 1934), with the majority of species in Malesia (Hou, 1960). All species of the genus are currently protected under CITES regulation and are considered endangered on the IUCN Red List of Threatened Species (IUCN 2018). So far, 21 species have been recorded in the world, among which four occur in Vietnam, namely $A$. crassna Pierre ex Lecomte, A. banaensae Phamh., A. baillonii Pierre ex Lecomte and A. rugosa L.C. Kiet \& Keßler (Ho 1992, Ho 2000, Kiet et al. 2005). Aquilaria yunnanensis was first described by S.C Huang in 1985, and this species has been supposed to be endemic in the Yunnan Province of China (Wang et al. 2007; Zhang et al 2019) In 2017 and 2018, during field trips in Dong Son Ky Thuong Nature Reserve, Quang Ninh Province (Fig. 1), we collected specimens of this species. After making elaborate observations, DNA analysis and comparison with the specimens of the closely related species in herbarium VNF this species has been confirmed as $A$. yunnanensis.

\section{Material and methods}

Specimens were collected from 9 individual trees of $A$. yunnanensis in Dong Son Ky Thuong Nature Reserve, Quang Ninh Province. Specimens include branchlets, leaves, flowers and fruits. The collected specimens were re-examined using comparative methods (Thin 2007) and molecular analysis. Voucher specimens are deposited in herbarium VNF. Conservation status of plant species base on IUCN criteria 2014.

Total DNA was isolated from leaf samples of Aquilaria with the Plant DNA Isolation kit (Qiagen, Germany). Five samples collected from 5 individual samples in the study area were used for DNA analysis: DT04, DT06, DT09, HBQN01 and TDC01. Concentration, purity and integrity levels of genomic DNA were determined by spectrophotometry and electrophoresis. The nucleotide sequences of DNA fragments were processed and analysed by specialized software such as BioEdit, DNAclub in GenBank. 
Table 1. List of primers to clone the fragments of DNA barcodes

\begin{tabular}{lll}
$\begin{array}{l}\text { Forward/Reve } \\
\text { rse primers }\end{array}$ & Primer sequence (dimensional 5'-3') & $\begin{array}{l}\text { Cloned fragments } \\
\text { of DNA barcode }\end{array}$ \\
\hline mP1F & 5'-ACCCAGTCCATCTGGAAATCTTGGTTC-3' \\
mP1R & 5'-CGTACAGTACTTTTGTGTTACGAG-3' \\
rp1F & 5'-ATGTCACCACAAACAGAGACTAAAGC-3' & matK \\
rp1R & 5'-GTAAAATCAAGTCCACCRCG-3' & rbcL \\
trnPF1 & 5'-GTTATGCATGAACGTAATGCTC-3' & trnH-psbA \\
psbPR1 & 5'-CGCGCATGGTGGATTCACAATCC-3' & ITS \\
IS2P1F & 5'-ATGCGATACTTGGTGTGAAT-3 & \\
IS2P1R & 5'-TCCTCCGCTTATTGATATGC-3' &
\end{tabular}

\section{Results}

\subsection{Taxonomic treatment:}

Aquilaria yunnanensis S. C. Huang, in Acta Bot. Yunnan. 7: 277 (1985); Wang et al. in Wu, Z. Y., Raven, P. H. \& Hong, D. Y. (eds.), in Flora of China 13: 214 (2007).

\subsection{Vietnamese name}

Dó vân nam.

\subsection{Type}

CHINA. Yunnan, Meng La, at 1200 m elev., 14 July 1963, Holotype - Yan-hiu Li 4593 (KUN).

\subsection{Morphological description}

Medium trees, up to $15 \mathrm{~m}$ tall, diameter up to $40 \mathrm{~cm}$. Branchlets dark brown, puberulous. Leaves simple, alternate; petiole 4-5 mm long, pubescent; Leaf blade elliptic-oblong or oblonglanceolate, 7-10 $\times 2-4 \mathrm{~cm}$, leathery, puberulous only on lower surface of the midrib, base cuneate or narrowly cuneate, apex caudate-acuminate 1.0-1.6 cm long, margin entire, upper surface dark green, smooth, lower surface light green; veins usually branched, dense, conspicuous and raised abaxially, obscure adaxially. Inflorescence terminal or axillary, consisting of 1, 2 or 3 umbels. Flowers fragrant; pedicel ca. $6 \mathrm{~mm}$ long, densely hairy. Calyx light yellow; tube campanulate, 6-8 $\mathrm{mm}$ long, exterior pubescent, interior 10-ribbed, ribs pubescent; lobes 5, ovate-oblong, ca. $3 \mathrm{~mm}$ long, densely pubescent both inside and outside. Petaloid appendages ca. $1.5 \mathrm{~mm}$ high, puberulous, apex rounded. Stamens 10, 1.5-2 mm long; anthers linear, introrse, ca. $1.0 \mathrm{~mm}$ long, filament pubescent, ca 1.0-1.3 mm long. Ovary subglobose, ca. $3 \mathrm{~mm}$ in diam, shiny, pubescent; style obscure; stigma capitate. Capsule obovoid, ca. $2.5 \times 1.7 \mathrm{~cm}$, base tapering and enclosed by erect, persistent calyx, corky when dried, apex rounded with apiculate tip; pericarp thickened, slightly rugose when dried, yellow pubescent. Fruit dehiscent with 2 valves stretched at acute angle. Seed(s) 1 or 2, ovoid, $6.5-7.5$ by $5.5-6.5 \mathrm{~mm}$, densely brown-yellow pubescent, apex obtuse; funicle $0.8-1 \mathrm{~cm}$ long, slightly shorter or longer than seed. 

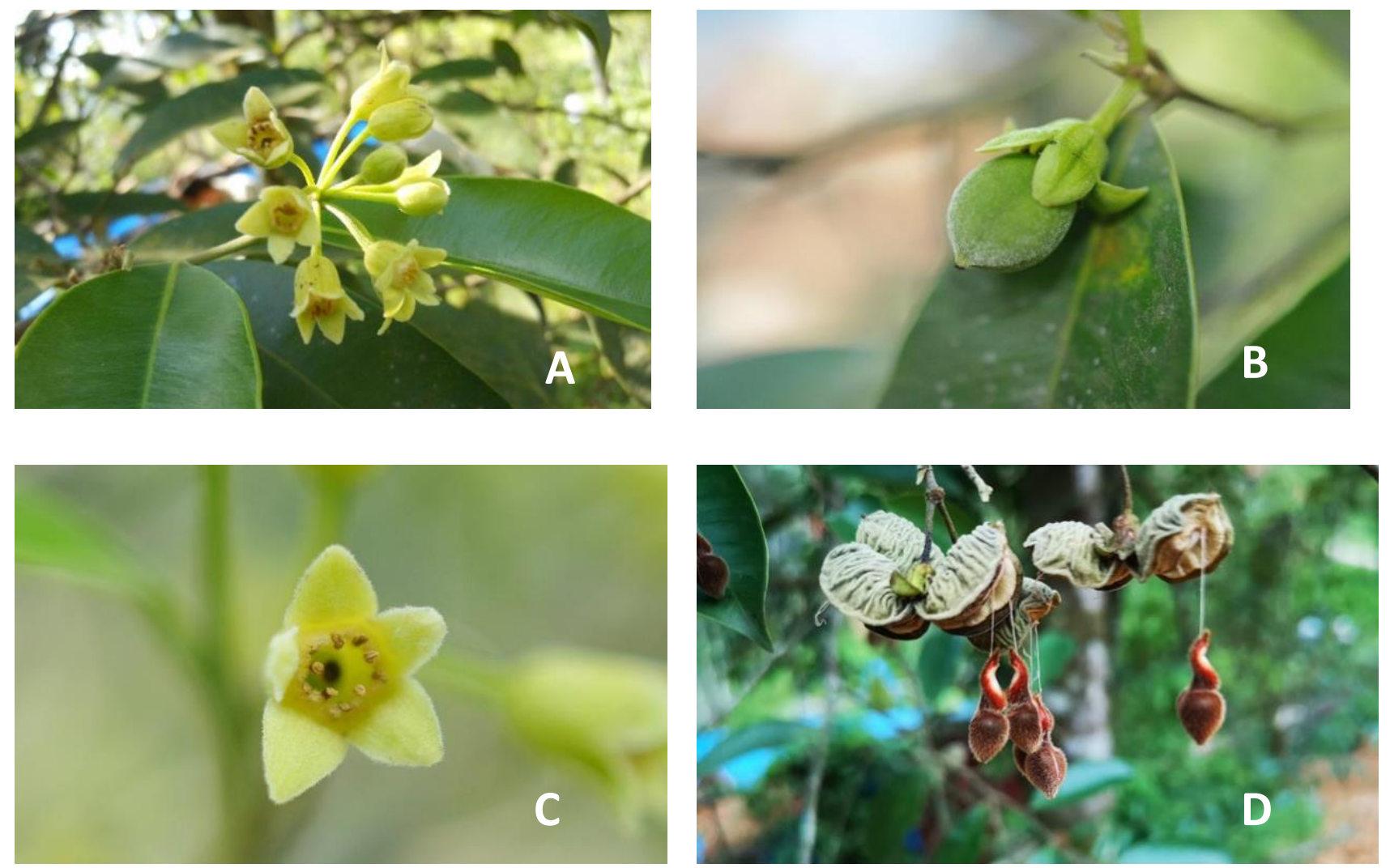

Figure 1. Aquilaria yunnanensis S. C. Huang: A. Branch with leaves and inflorescence; B. Fruit; C. Flower; D. Fruits open into 2 valves

\subsection{Specimens examined}

VIETNAM. Quang Ninh province, Hoang Bo district, Dong Son Ky Thuong Nature Reserve. Specimens in VNF; Nguyen DT04, specimen with fruits, 21.08'.147" N 107.05'.593"E, 28 June 2018, alt. $432 \mathrm{~m}$; Nguyen DT06, specimen with fruits, 21.08'.172" N 107.05'.577"E, 28 June 2018, alt. 436 m; Nguyen DT09, specimen with fruits, 21.08'.186" N 107.05'.604" E, 28 June 2018, alt. 450 m;

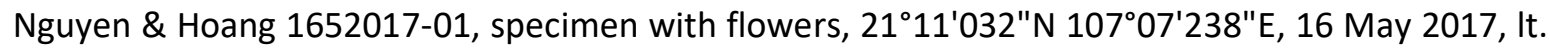
$460 \mathrm{~m}$; Nguyen \& Hoang 1652017-02, specimen with flowers, $21^{\circ} 11^{\prime} 032^{\prime \prime} \mathrm{N} 107^{\circ} 07^{\prime} 238^{\prime \prime} \mathrm{E}, 16$ May 2017, It. 460 m; Duong HBQN01DT04, specimen with flowers, 21.08'.147" N 107.05'.593"E, 16 May 2017, It. 432 m; Duong TDC01, specimen with flowers, 21.09'313" N 106.52.267" E, 16 May 2017, It. $423 \mathrm{~m}$.

\subsection{Note}

According to Wang et al. (2007), A. yunnanensis are small tree 3-8 m tall. However, in our research area we found 5 trees up to $15 \mathrm{~m}$ tall and $40 \mathrm{~cm}$ in diameter.

\subsection{Distribution}

China (Yunnan) and Vietnam (Dong Son Ky Thuong Nature Reserve, Quang Ninh Province). 


\subsection{Ecology}

Aquilaria yunnanensis grows in natural forests in Dong So Ky Thuong Nature Reserve at altitudes from 400 to $480 \mathrm{~m}$. In Yunnan, China, the species is distributed in ca. $1200 \mathrm{~m}$ Wang et al. (2007).

\subsection{Conservation status}

According to IUCN Red List 2019, Aquilaria yunnanensis is listed as Vulnerable (VU). Based on the result of our study, the number of mature individuals are only 9 in Dong Son Ky Thuong Nature Reserve, Quang Ninh province; this number is much smaller than criteria of IUCN (2014). (If any plant species has population smaller than 250 mature individuals, it should be listed as Critical Endangered (CR), additional also under threat from local people in the study area therefore, we propose this species should be listed as Critical Endangered (CR) in the Red Data Book and needs to be conserved in Vietnam. This species also should be upgraded to Endangered (EN) on the IUCN Red list.

\subsection{Economic value}

Similar to Aquilaria crassa, A.yunnanensis provides a high content and good quality resin (Hoang et al. in press), which is commonly used in the cosmetic industry, especially in producing perfume. Hence, this species should be considered as a high potential plant species for economic development of local people at least in the research area.

\subsection{Phenology}

Flowering from April to June and fruiting from June to August (based on the result of field observation).

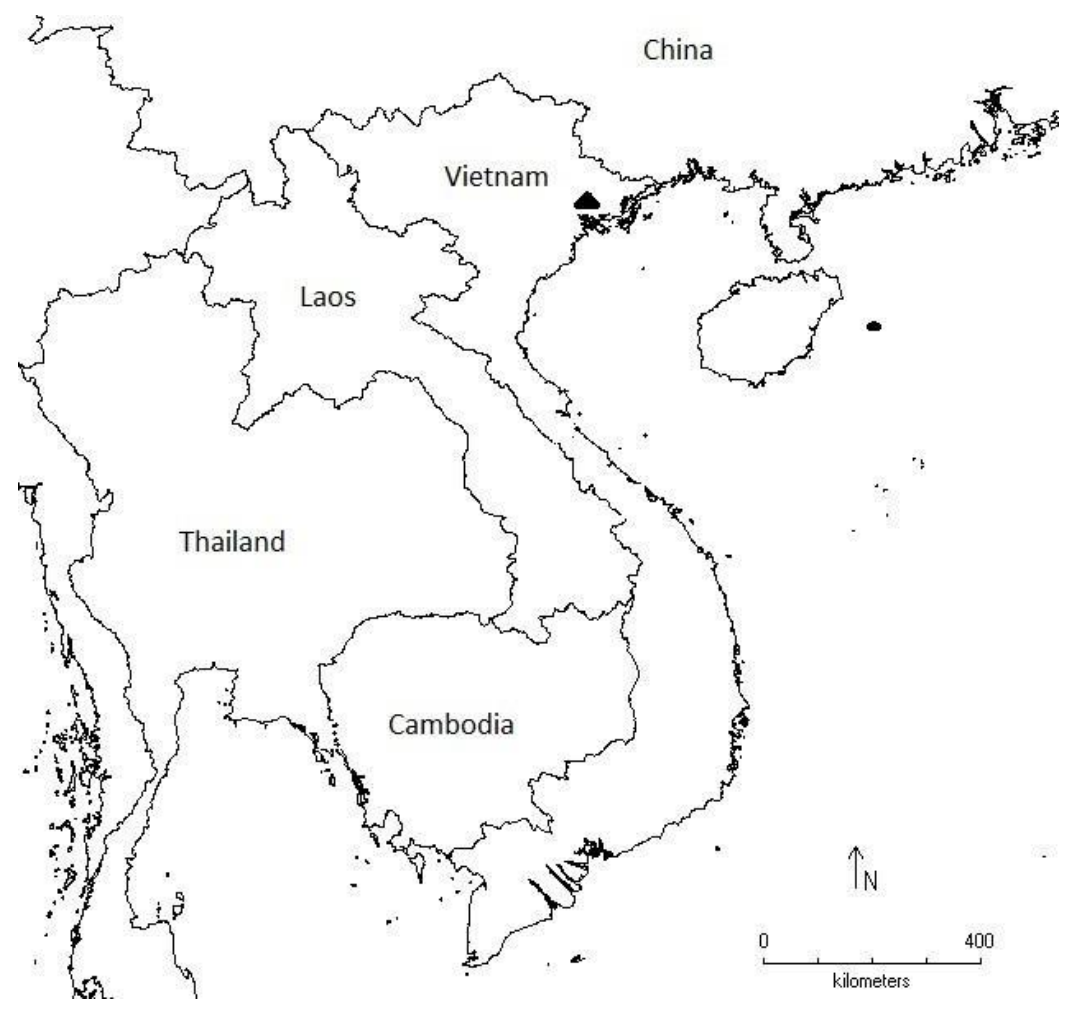

Figure 2. Map on the distribution of A.yunnanensis in Vietnam 


\subsection{GenBank accession no:}

KU244235.1 (rbcL) KY927340.1 (matK), KY927208.1 (trnH-psbA) and MH134148.1 (ITS2); we sequenced the specimen DT04, DT06, DT09, HBQN01 and TDC01

\subsection{DNA analysis:}

The results of sequence analyzing shown that matK, $r b c \mathrm{~L}$, trnH-psbA and ITS2 fragments with lengths of $852 \mathrm{bp}, 588 \mathrm{bp}, 441 \mathrm{bp}$ and $393 \mathrm{bp}$ respectively.

Table 2. Comparison of the nucleotide sequences of investigated samples of ITS2 locus with Aquilaria yunnanensis MH134148.1

\begin{tabular}{lcclll}
\hline Sample code & Positions & & & $\begin{array}{c}\text { Differential } \\
\text { nucleotides }\end{array}$ & Similarity (\%) \\
\hline DT04 & 70 & 318 & 359 & & \\
DT06 & C & C & C & 0 & 100.00 \\
DT09 & C & C & C & 0 & 100.00 \\
HBQN01 & T & T & T & 3 & 99.24 \\
TDC01 & C & C & C & 0 & 100.00 \\
MH134148.1 & C & C & C & 0 & 100.00 \\
\hline
\end{tabular}

Results of comparing the sequence of 4 DNA fragments of 5 samples with A. yunnanensis (MH134148.1) in the NCBI Genbank show that there were no differences in the three DNA fragments (matK, rbcL, trnH-psbA) for all samples. For locus ITS2, the DT04, DT06, HBQN01 and TDC01 were the same A. yunnanensis (MH134148.1), a small difference $(0.76 \%)$ was found in the DT09 sample.

Table 3. Morphological comparison among Aquilaria species

\begin{tabular}{|c|c|c|c|c|}
\hline Characters & $\begin{array}{l}\text { Aquilaria } \\
\text { yunnanensis }\end{array}$ & $\begin{array}{l}\text { Aquilaria } \\
\text { cassna }^{1}\end{array}$ & $\begin{array}{l}\text { Aquilaria } \\
\text { sinensis }^{2}\end{array}$ & Aquilaria rugosa ${ }^{3}$ \\
\hline Size & $\begin{array}{l}\text { Medium trees, up } \\
\text { to } 15 \mathrm{~m} \text { tall }\end{array}$ & $\begin{array}{l}\text { Big trees, up } \\
\text { to } 30 \mathrm{~m} \text { tall }\end{array}$ & $\begin{array}{l}\text { Medium trees, up } \\
\text { to } 15 \mathrm{~m} \text { tall }\end{array}$ & $\begin{array}{l}\text { Small trees, up to } 10 \\
\mathrm{~m} \text { tall }\end{array}$ \\
\hline Leaf shape & $\begin{array}{l}\text { Elliptic-oblong or } \\
\text { oblong-lanceolate, } \\
\text { rarely obovate }\end{array}$ & Elliptic & $\begin{array}{l}\text { Orbicular, elliptic- } \\
\text { oblong, obovate }\end{array}$ & Ovate to obovate \\
\hline $\begin{array}{l}\text { Capsule } \\
\text { shape }\end{array}$ & $\begin{array}{l}\text { Obovoid, slightly } \\
\text { compressed }\end{array}$ & $\begin{array}{l}\text { Round, } \\
\text { obovoid }\end{array}$ & Ovoid & Globose or pyriform \\
\hline Valves & $\begin{array}{l}\text { Valves thin, } \\
\text { stretched at acute } \\
\text { angle }\end{array}$ & $\begin{array}{l}\text { Valves } \\
\text { medium }\end{array}$ & Valves medium & $\begin{array}{l}\text { Valves thick, angle of } \\
\text { dehiscence to } 180^{\circ}\end{array}$ \\
\hline $\begin{array}{l}\text { Surface of } \\
\text { Capsule }\end{array}$ & Slightly rugose & $\begin{array}{l}\text { Heavily } \\
\text { wrinkled }\end{array}$ & $\begin{array}{l}\text { White silky or } \\
\text { smooth }\end{array}$ & Rugose \\
\hline
\end{tabular}




\begin{tabular}{|c|c|c|c|c|c|}
\hline Pericarp & $\begin{array}{l}\text { Pericarp thick and } \\
\text { slightly rugose } \\
\text { when dry }\end{array}$ & $\begin{array}{l}\text { Pericarp } \\
\text { thick, smooth } \\
\text { when dry }\end{array}$ & $\begin{array}{l}\text { Pericarp } \\
\text { smooth wh }\end{array}$ & $\begin{array}{l}\text { thin, } \\
\text { ndry }\end{array}$ & $\begin{array}{l}\text { Pericarp thick and } \\
\text { rugose when dry }\end{array}$ \\
\hline $\mathrm{Se}$ & $\begin{array}{l}\text { Seed(s) } 1 \text { or } 2 \text {, } \\
\text { densely } \begin{array}{l}\text { brown- } \\
\text { yellow pubescent }\end{array}\end{array}$ & $\begin{array}{l}\text { Seed(s) } 2, \\
\text { black, } \\
\text { glabrous }\end{array}$ & $\begin{array}{l}\text { Seeds } 2 \\
\text { sericeous } \\
\text { glabrous }\end{array}$ & $\begin{array}{r}\text { white } \\
\text { or }\end{array}$ & $\begin{array}{l}\text { Seeds } 2 \text { dark-brown, } \\
\text { densely covered with } \\
\text { brownish hairs }\end{array}$ \\
\hline $\mathrm{Fu}$ & $\begin{array}{l}\text { Funicle slightly } \\
\text { shorter than seed }\end{array}$ & $\begin{array}{l}\text { Funicle longer } \\
\text { than seed }\end{array}$ & $\begin{array}{l}\text { Funicle } \\
\text { than seed }\end{array}$ & longer & Funicle as long as seed \\
\hline
\end{tabular}

${ }^{1}$ Ho 1992, field observation and specimens in VNF (Nguyen Thanh Tuan QN04; Nguyen The Nha QN01; Nguyen The Nha PQ08; Nguyen The Nha PQ02); ${ }^{2}$ Wang et al. 2007; ${ }^{3}$ Kiet et al. 2005, field observation and specimens in VNF (Phan Duc Le SN02; Nguyen The Nha ST02).

\section{Conclusion}

Our study confirms that Vietnam is home to five Aquilaria species, including $A$. yunnanensis. The study also provides useful information for the conservation of the important Aquilaria species in Vietnam as well as in the region.

\section{Acknowledgement}

The authors are grateful to the Vietnamese government for financial support of this study (Project number NĐT.10.GER/16 and grant number 106.06-2018.23). The authors also would like to thank the Vietnam National University of Forestry and the Institute for Bio- and Geoscience, Jülich Institute, Germany for their support. Grateful thanks also to the leader and staff of the Dong Son Ky Thuong Nature Reserve for their help during the field trip. Special thanks to Prof. Dr. Paul Keßler Leiden University, Hortus botanicus, The Netherlands and Dr. Anna Jasinska, Institute of Dendrology, Polish Academy of Sciences, Poland for their valuable comments.

\section{References}

Ban, N.T (ed). (2007). Vietnam Red Data Book. (Vol. 2). Natural Science and Technology Publishing house. Hanoi, Vietnam

Domke, W. (1934). Untersuchungen über die systematische und geographische Gliederung der Thymelaeaceen. Biblioth. Bot., 27, Heft 111: 1-151.

Ho, P. H. (1992). Thymelaeaceae. In Morat, Ph. (ed) Flore Cambodge, Laos \& Vietnam, 26, pp. 3852. Muséum National d'Histoire Naturelle, Paris.

Hou, D. (1960). Thymelaeaceae. In Van Steenis, C. G. G. J. (ed). Flora Malesiana, 6, pp. 1-59. Rijksherbarium, Leiden.

IUCN Red List of Threatened Species (2018). http://dx.doi.org/10.2305/IUCN.UK.20181.RLTS.T191318A1975746.en. Downloaded on 10 January 2019

IUCN Standards and Petitions Subcommittee. (2014). Guidelines for Using the IUCN Red List Categories and Criteria. Version 11. Prepared by the Standards and Petitions Subcommittee. Downloadable from http://www.iucnredlist.org/documents/RedListGuidelines.pdf.

Kiet, L. C. , Kessler, P. J. A. \& Eurlings., M. (2005). A new species of Aquilaria (Thymelaeaceae) from Vietnam. Blumea 50: 135-141.

Hoang, V.S., Nguyen, T.N., Le, B.T., Nguyen, T.T. Tran, N.H, Pham,T.H., Phung, T.T., Hoang, T.H., Nguyen, T.T., Claudio C., Olarte A., Nguyen M.D. Conservation status of Aquilaria species and high quality of agarwood production in Vietnam (in press). 
Thin, N. N. (2007). Plant research methodology. Publishing house of Hanoi National University. Hanoi

Zhang, Y. H., Huang, Y., Li, Z. M., \& Zhang, S. D. (2019). Characterization of the complete chloroplast genome of the vulnerable agarwood tree, Aquilaria yunnanensis (Thymelaeaceae). Conservation Genetics Resources, 11(2), 161-164.doi: https://doi.org/10.1007/s12686-018-0989-0

Wang, Y., Lorin I. N., Michael G. G., Brian M., Christopher D. B. \& Lorin I. N., Thymelaeaceae in Wu, Z. Y., Raven, P. H. \& Hong, D. Y. (eds.) (2007). Flora of China, 13. Page 214. 